\title{
KONTRADIKSI DASAR PENGENAAN PAJAK PERATURAN PEMERINTAH NOMOR 46 TAHUN 2013
}

\author{
Puan Indri Hazimah \\ Ferry Irawan \\ Politeknik Keuangan Negara STAN \\ idrpuan@gmail.com \\ ferry.irawan@pknstan.ac.id
}

\begin{abstract}
This research tries to elaborate the contradiction between Government Regulation number 46 of 2013 (PP 46/2013) and Article 4 paragraph 1 Law number 36 of 2008 (Income Tax Law) in addressing tax base. Also, it describes income tax simulation from PP 46/2013 an Income Tax Law perspective. This research is designed by applying literature review and field study method. We collect and analysis data throughout laws, text-books, and journals to obtain a a suitable framework related to the case discussed. Furthermore, we also conduct interview to find practical experience that cannot be found in literatures. A deepinterview is applied to the relevant officials. The result shows that usage of gross revenue to calculate tax base based on PP 46/2013 is quite suitable with the objective of the regulation, to simplify and support tax payers in fulfilling their tax-obligation. On the other hand, although the revenue is not appropriate with the definition of Income tax law, every additional economic capability, the provision is not against general rules. This is occurred because Article 17 paragraph 7 and Article 4 paragraph 2 letter (a) Income Tax Law allow certain income will be imposed by final income tax.
\end{abstract}

Keyword: Tax Base, Income, Gross Revenue, PP 46/2013

\section{PENDAHULUAN}

Untuk dapat meningkatkan penerimaan pajak, pemerintah harus membuat kebijakan yang dapat mengoptimalisasi pendapatan pajak dari masyarakat yang berpotensi, misalnya sektor Usaha Mikro, Kecil, dan Menengah (selanjutnya disebut dengan UMKM). Jumlah UMKM di Indonesia mencapai 57,8 juta unit usaha menurut data Badan Pusat Statistik. Pada akhir 2016, Kementerian Koperasi dan UKM mencatat 60,34\% dari PDB Indonesia dihasilkan oleh sektor UMKM. Namun hal tersebut berbanding terbalik dengan kontribusinya terhadap 
penerimaan pajak, yaitu hanya sebesar 5\%. Menindaklanjuti hal tersebut, pada tahun 2013 pemerintah mengeluarkan kebijakan mengenai pengenaan pajak bersifat final yang tertuang dalam Peraturan Pemerintah Nomor 46 Tahun 2013 (selanjutnya disebut dengan PP 46) dan mulai berlaku sejak 1 Juli 2013. Kebijakan tersebut ditujukan kepada Wajib Pajak y ang menerima penghasilan dari usaha, tidak termasuk penghasilan dari jasa sehubungan dengan pekerjaan bebas dan bentuk usaha tetap, dengan peredaran bruto tidak melebihi $\mathrm{Rp}$ 4.800.000.000,00 (empat miliar delapan ratus juta rupiah) dalam 1 (satu) Tahun Pajak.

Peraturan Pemerintah ini mengatur omzet atau peredaran bruto pengusaha UMKM sebagai Dasar Pengenaan Pajak PP 46. Dengan kata lain, hanya mempertimbangkan omzet/peredaran usaha saja tanpa melihat aspek lainnya seperti biaya dan kerugian usaha. Pasal 4 Ayat (1) Undang-Undang Nomor 36 Tahun 2008 tentang Pajak Penghasilan (selanjutnya disebut dengan UU PPh) mendefinisikan penghasilan seperti berikut: "Yang menjadi Objek Pajak adalah penghasilan, yaitu setiap tambahan kemampuan ekonomis yang diterima atau diperoleh Wajib Pajak...". Pengertian ini mengindikasikan bahwa yang menjadi penghasilan adalah tambahan kemampuan ekonomis Wajib Pajak. Kontradiksi muncul karena PP 46 menyebutkan bahwa Dasar Pengenaan Pajaknya adalah omzet/peredaran usaha yang tidak mencerminkan tambahan kemampuan ekonomis jika mempertimbangkan aspek lain sebagaimana dimaksud di atas.

Penelitian ini bertujuan untuk menjelaskan kontradiksi antara Dasar Pengenaan Pajak Peraturan Pemerintah Nomor 46 Tahun 2013 dengan Pasal 4 Ayat (1) Undang-Undang Nomor 36 Tahun 2008 dan menjelaskan simulasi penghitungan Pajak Penghasilan dengan basis Dasar Pengenaan Pajak Peraturan Pemerintah 46 Tahun 2013 dan Undang-Undang Nomor 36 Tahun 2008. 


\section{TELAAH LITERATUR DAN PENGEMBANGAN HIPOTESIS}

\section{Dasar Pengenaan Pajak Penghasilan Menurut Peraturan Pemerintah Nomor 46 Tahun 2013}

Berdasarkan Pasal 4 Ayat (1) PP 46, Dasar Pengenaan Pajak yang digunakan adalah jumlah peredaran bruto. Peredaran bruto menurut SE66/PJ/2010 adalah penghasilan yang diterima atau diperoleh dari kegiatan usaha sebelum dikurangi biaya untuk mendapatkan, menagih, dan memelihara penghasilan baik yang berasal dari Indonesia maupun dari luar Indonesia.

Adapun pendapatan yang diperhitungkan dalam menentukan peredaran bruto yang tidak melebihi Rp 4.800.000.000,00 adalah pendapatan berupa :

1. penghasilan dari pekerjaan dalam hubungan kerja seperti gaji, honorarium, dan penghasilan dari praktik pengacara, akuntan, arsitek, dokter, konsultan, notaris, penilai, dan aktuaris;

2. penghasilan dari usaha dan kegiatan;

3. penghasilan dari modal, baik berupa harta gerak seperti kendaraan dan bangunan maupun tak gerak seperti bunga, dividen, royalti, sewa, dan keuntungan pengalihan harta; dan

4. penghasilan lain-lain seperti pembebasan utang dan pemberian hadiah.

Namun tidak termasuk peredaran bruto dari :

1. jasa sehubungan dengan pekerjaan bebas;

2. penghasilan yang diterima atau diperoleh dari luar negeri;

3. usaha yang atas penghasilannya telah dikenai $\mathrm{PPh}$ Final tersendiri; dan

4. penghasilan yang bukan objek pajak.

Sebagaimana disebutkan dalam Pasal 2 PP 46, yang dimaksud dengan jasa sehubungan dengan pekerjaan bebas adalah jasa yang dihasilkan oleh seorang:

1. tenaga ahli yang melakukan pekerjaan bebas seperti pengacara, akuntan, arsitek, dokter, konsultan, notaris, penilai, dan aktuaris; 
2. pemain musik, pembawa acara, penyanyi, pelawak, bintang film, bintang sinetron, bintang iklan, sutradara, kru film, foto model, peragawan, pemain drama, penari;

3. olahragawan;

4. penasihat, pengajar, pelatih, penceramah, penyuluh, dan moderator;

5. pengarang, peneliti, dan penerjemah;

6. agen iklan;

7. pengawas atau pengelola proyek;

8. perantara (makelar/calo);

9. penjaja barang dagangan;

10. agen asuransi; dan

11. distributor perusahaan pemasara berjenjang atau penjualan langsung dan kegiatan sejenis lainnya.

\section{Dasar Pengenaan Pajak Penghasilan Menurut Undang-Undang Nomor 36}

\section{Tahun 2008}

Pasal 4 Ayat (1) UU PPh mengamanatkan bahwa yang menjadi objek pajak adalah penghasilan, yaitu setiap tambahan kemampuan ekonomis yang diterima atau diperoleh Wajib Pajak, baik yang berasal dari Indonesia maupun dari luar Indonesia, yang dapat dipakai untuk konsumsi atau untuk menambah kekayaan Wajib Pajak yang bersangkutan, dengan nama dan dalam bentuk apa pun, termasuk:

a. penggantian atau imbalan berkenaan dengan pekerjaan atau jasa yang diterima atau diperoleh termasuk gaji, upah, tunjangan, honorarium, komisi, bonus, gratifikasi, uang pensiun, atau imbalan dalam bentuk lainnya, kecuali ditentukan lain dalam undang-undang ini;

b. hadiah dari undian atau pekerjaan atau kegiatan, dan penghargaan;

c. laba usaha;

d. keuntungan karena penjualan atau karena pengalihan harta termasuk:

1. keuntungan karena pengalihan harta kepada perseroan, persekutuan, dan badan lainnya sebagai pengganti saham atau penyertaan modal; 
2. keuntungan karena pengalihan harta kepada pemegang saham, sekutu, atau anggota yang diperoleh perseroan, persekutuan, dan badan lainnya;

3. keuntungan karena likuidasi, penggabungan, peleburan, pemekaran, pemecahan, pengambilalihan usaha, atau reorganisasi dengan nama dan dalam bentuk apa pun;

4. keuntungan karena pengalihan harta berupa hibah, bantuan, atau sumbangan, kecuali yang diberikan kepada keluarga sedarah dalam garis keturunan lurus satu derajat dan badan keagamaan, badan pendidikan, badan sosial termasuk yayasan, koperasi, atau orang pribadi yang menjalankan usaha mikro dan kecil, yang ketentuannya diatur lebih lanjut dengan Peraturan Menteri Keuangan, sepanjang tidak ada hubungan dengan usaha, pekerjaan, kepemilikan, atau penguasaan di antara pihak-pihak yang bersangkutan; dan

5. keuntungan karena penjualan atau pengalihan sebagian atau seluruh hak penambangan, tanda turut serta dalam pembiayaan, atau permodalan dalam perusahaan pertambangan;

e. penerimaan kembali pembayaran pajak yang telah dibebankan sebagai biaya dan pembayaran tambahan pengembalian pajak;

f. bunga termasuk premium, diskonto, dan imbalan karena jaminan pengembalian utang;

g. dividen, dengan nama dan dalam bentuk apapun, termasuk dividen dari perusahaan asuransi kepada pemegang polis, dan pembagian sisa hasil usaha koperasi;

h. royalti atau imbalan atas penggunaan hak;

i. sewa dan penghasilan lain sehubungan dengan penggunaan harta;

j. $\quad$ penerimaan atau perolehan pembayaran berkala;

k. keuntungan karena pembebasan utang, kecuali sampai dengan jumlah tertentu yang ditetapkan dengan Peraturan Pemerintah;

1. keuntungan selisih kurs mata uang asing;

m. selisih lebih karena penilaian kembali aktiva;

n. premi asuransi; 
o. iuran yang diterima atau diperoleh perkumpulan dari anggotanya yang terdiri dari Wajib Pajak yang menjalankan usaha atau pekerjaan bebas;

p. tambahan kekayaan neto yang berasal dari penghasilan yang belum dikenakan pajak;

q. penghasilan dari usaha berbasis syariah;

r. imbalan bunga sebagaimana dimaksud dalam Undang-Undang yang mengatur mengenai ketentuan umum dan tata cara perpajakan; dan

s. $\quad$ surplus Bank Indonesia

Pasal 16 UU PPh menjelaskan bahwa Dasar Pengenaan Pajak Wajib Pajak Orang Pribadi adalah Penghasilan Neto-Penghasilan Tidak Kena Pajak, sedangkan Wajib Pajak Badan adalah Penghasilan Neto (penghasilan bruto dikurangi dengan biaya untuk mendapatkan, menagih, dan memelihara penghasilan atau biaya yang diperkenankan dalam Pasal 6 UU PPh). Lain halnya dengan Wajib Pajak Luar Negeri, Dasar Pengenaan Pajaknya ialah Penghasilan Bruto.

\section{Kontradiksi Dasar Pengenaan Pajak Menurut Peraturan Pemerintah Nomor} 46 Tahun 2013 dan Pasal 4 Ayat (1) Undang-Undang Nomor 36 Tahun 2008

Sesuai penjelasan pada subbab sebelumnya, PP 46 menjadikan omzet atau peredaran bruto pengusaha UMKM sebagai Dasar Pengenaan Pajak. Dengan kata lain, hanya melihat seluruh penghasilan saja tanpa melihat aspek lainnya seperti biaya dan kerugian usaha yang ditanggung paraengusaha. Bertentangan dengan hal itu, Pajak Penghasilan sesuai dengan yang diamanatkan oleh UU PPh mengambil pengertian Penghasilan sebagaimana seperti yang disebutkan dalam Pasal 4 Ayat (1) UU tersebut, yang berbunyi "Yang menjadi objek pajak adalah penghasilan, yaitu setiap tambahan kemampuan ekonomis yang diterima atau diperoleh Wajib Pajak...". Pengertian tersebut memaparkan adanya kontradiksi, di mana peredaran bruto belum tentu menjadi tambahan kemampuan ekonomis jika mempertimbangkan aspek lain yang penulis sebutkan di atas. 


\section{METODE PENELITIAN DAN PEMBAHASAN}

Penulis melakukan pengumpulan dan analisis data dengan menelusuri berbagai macam sumber, seperti peraturan perundang-undangan, buku, artikel, dan jurnal ilmiah untuk memeroleh landasan teoritis mengenai permasalahan yang akan dibahas. Selain itu, penulis juga melakukan teknik wawancara dengan tujuan untuk mendapatkan data yang tidak dapat ditemukan di sumber-sumber pustaka. Wawancara dilakukan dengan cara tanya jawab kepada pihak yang berwenang terkait permasalahan yang dibahas dan data yang dibutuhkan.

Bertentangan dengan penjelasan pasal 4 ayat (1) UU PPh, PP 46 memakai omzet/peredaran usaha sebagai Dasar Pengenaan Pajak untuk menghitung pajak final yang terutang. Hal yang menimbulkan kontradiksi ini kemudian dipatahkan oleh pasal yang menjadi penimbang PP 46 dikeluarkan, yaitu Pasal 17 Ayat (7) UU PPh dan penjelasannya serta Pasal 4 Ayat (2) huruf e UU PPh.

Pasal 17 Ayat (7) UU PPh menyatakan bahwa, "Dengan Peraturan Pemerintah dapat ditetapkan tarif pajak tersendiri atas penghasilan sebagaimana dimaksud dalam Pasal 4 Ayat (2), sepanjang tidak melebihi tarif pajak tertinggi sebagaimana dimaksud pada ayat (1)”. Lebih lanjut, Penjelasan Pasal 17 Ayat (1) menjabarkan pasal tersebut sebagai berikut.

"Ketentuan dalam ayat ini memberi wewenang kepada Pemerintah untuk menentukan tarif pajak tersendiri yang dapat bersifat final atas jenis penghasilan tertentu sebagaimana dimaksud dalam Pasal 4 Ayat (2), sepanjang tidak lebih tinggi dari tarif pajak tertinggi sebagaimana diatur dalam ayat (1). Penentuan tarif pajak tersendiri tersebut didasarkan atas pertimbangan kesederhanaan, keadilan dan pemerataan dalam pengenaan pajak".

Adapun pernyataan Pasal 17 Ayat (7) dan penjelasannya di atas merujuk pada Pasal 4 Ayat (2) huruf e UU PPh yang berbunyi, "Penghasilan di bawah ini dapat dikenai pajak bersifat final: e. penghasilan tertentu lainnya; yang diatur dengan atau berdasarkan Peraturan Pemerintah”. Adapun tujuan pengenaan final pada penghasilan tertentu dapat dilihat pada bagian penjelasan dari Pasal 4 Ayat (2) UU PPh sebagai berikut. 
"Sesuai dengan ketentuan pada ayat (1), penghasilan-penghasilan sebagaimana dimaksud pada ayat ini merupakan objek pajak. Berdasarkan pertimbangan pertimbangan antara lain: -perlu adanya dorongan dalam rangka perkembangan investasi dan tabungan masyarakat; -kesederhanaan dalam pemungutan pajak; berkurangnya beban administrasi baik bagi Wajib Pajak maupun Direktorat Jenderal Pajak; -pemerataan dalam pengenaan pajaknya; dan -memerhatikan perkembangan ekonomi dan moneter, atas penghasilan-penghasilan tersebut perlu diberikan perlakuan tersendiri dalam pengenaan pajaknya. Perlakuan tersendiri dalam pengenaan pajak atas jenis penghasilan tersebut termasuk sifat, besarnya, dan tata cara pelaksanaan pembayaran, pemotongan, atau pemungutan diatur dengan Peraturan Pemerintah."

Pernyataan "Penentuan tarif pajak tersendiri tersebut didasarkan atas pertimbangan kesederhanaan...." pada penjelasan Pasal 17 Ayat (7) UU PPh dan pernyataan “....kesederhanaan dalam pemungutan pajak...” pada penjelasan Pasal 4 Ayat (2) UU PPh selaras dengan pembukaan PP 46 yaitu pertimbangan bahwa Peraturan Pemerintah ini diterbitkan untuk memberikan kemudahan kepada Wajib Pajak orang pribadi dan badan yang memiliki peredaran tertentu.

Hal tersebut menjawab kontradiksi yang menjadi permasalahan dalam tulisan ini bahwa sebenarnya pemakaian omzet/peredaran bruto sebagai Dasar Pengenaan Pajak PP 46 sejalan dengan tujuan penerbitan peraturan ini, yaitu untuk kemudahan dan kesederhanaan bagi Wajib Pajak, karena apabila dasar yang digunakan adalah tambahan kemampuan ekonomis seperti yang disebut dalam Pasal 4 Ayat (1) UU PPh, maka Wajib Pajak harus menghitung berapa tambahan kemampuan ekonomisnya melalui pembukuan, di mana pengguna PP 46 yaitu pelaku UMKM tidak menggunakannya dan pastilah tujuan penerbitan peraturan ini tidak akan tercapai. Selain itu, jelas sudah bahwa pemakaian omzet/peredaran bruto sebagai Dasar Pengenaan Pajak PP 46 tidaklah bertentangan dengan UU PPh karena pada kenyataannya UU PPh mengizinkan adanya jenis penghasilan yang dikenai tarif berbeda dengan apa yang telah ditetapkan oleh undang-undang. Penggunaan omzet/peredaran bruto sebagai Dasar Pengenaan Pajak PP 46 didasarkan pada kemudahan dalam penggunaannya, sesuai dengan salah satu asas 
pemungutan pajak yaitu kesederhanaan (simplicity). Namun, kemudahan ini jelas dapat menimbulkan perbedaan pada jumlah pajak yang seharusnya terutang karena PP 46 tidak memasukkan unsur pengurang seperti biaya dan kerugian usaha layaknya UU PPh. Dalam keadaan untung, mungkin pajak terutang perusahaan akan lebih kecil jika memakai tarif final 1\% PP 46 dibandingkan tarif 25\% Pasal 17 Ayat (1) UU PPh, tetapi dalam keadaan sebaliknya (rugi) perusahaan akan menanggung pajak terutang yang lebih besar. Untuk membuktikan hal tersebut, penulis membuat simulasi penghitungan pajak terutang perusahaan dalam keadaan untung dan rugi seperti yang terlihat di tabel berikut. 
Tabel 1.1

Kondisi 1

Perusahaan Mengalami Keuntungan

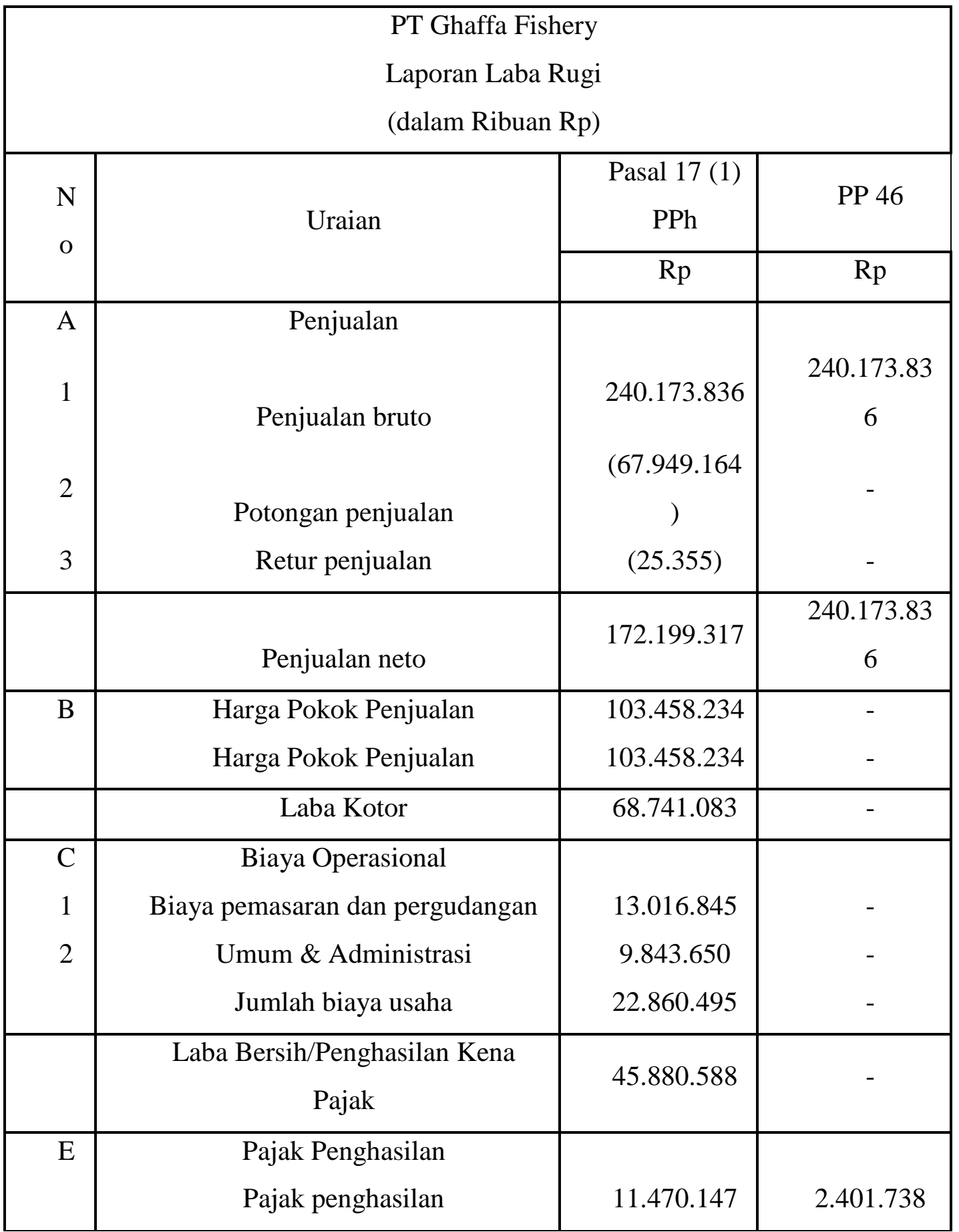


Tabel 1.2

Kondisi 2

Perusahaan Mengalami Kerugian

\begin{tabular}{|c|c|c|c|}
\hline \multicolumn{4}{|c|}{$\begin{array}{l}\text { PT Ghaffa Fishery } \\
\text { Laporan Laba Rugi } \\
\text { (dalam Ribuan Rp) }\end{array}$} \\
\hline \multirow[t]{2}{*}{ No } & \multirow[t]{2}{*}{ Uraian } & $\begin{array}{c}\text { Pasal } 17(1) \\
\text { PPh }\end{array}$ & PP 46 \\
\hline & & $\mathrm{Rp}$ & $\mathrm{Rp}$ \\
\hline $\mathrm{A}$ & $\begin{array}{c}\text { Penjualan } \\
\text { Penjualan bruto } \\
\text { Potongan penjualan } \\
\text { Retur penjualan }\end{array}$ & $\begin{array}{c}265.284 .916 \\
(67.949 .164) \\
(25.355)\end{array}$ & $\begin{array}{c}265.284 .916 \\
- \\
-\end{array}$ \\
\hline & Penjualan neto & 197.310 .397 & 265.284 .916 \\
\hline $\mathrm{B}$ & $\begin{array}{l}\text { Harga Pokok Penjualan } \\
\text { Harga Pokok Penjualan }\end{array}$ & $\begin{array}{l}234.458 .678 \\
234.458 .678\end{array}$ & - \\
\hline & Laba Kotor & $(37.148 .281)$ & - \\
\hline $\begin{array}{l}\mathrm{C} \\
1 \\
2\end{array}$ & $\begin{array}{c}\text { Biaya Operasional } \\
\text { Biaya pemasaran dan pergudangan } \\
\text { Umum \& Administrasi } \\
\text { Jumlah biaya usaha }\end{array}$ & $\begin{array}{l}14.017 .845 \\
11.843 .650 \\
25.861 .495\end{array}$ & $\begin{array}{l}- \\
- \\
-\end{array}$ \\
\hline & Laba Bersih/Penghasilan Kena Pajak & $(63.009 .776)$ & - \\
\hline $\mathrm{E}$ & $\begin{array}{l}\text { Pajak Penghasilan } \\
\text { Pajak penghasilan }\end{array}$ & - & 2.652 .849 \\
\hline
\end{tabular}

Kedua kondisi di atas menggambarkan dengan tepat implikasi dipakainya omzet/peredaran bruto sebagai Dasar Pengenaan Pajak PP 46. Dalam keadaan untung, pajak terutang yang harus dibayar perusahaan jauh lebih kecil jika perusahaan memakai PP 46 daripada Pasal 17 Ayat (1) UU PPh. Sebaliknya, PP 46 akan menjadi beban tambahan bagi perusahaan yang sedang mengalami rugi. Lebih 
lanjut, dapat kita lihat bahwa persentase dari Penghasilan Kena Pajak (PKP) terhadap Penghasilan Bruto yang diperoleh kedua kondisi tersebut berbeda. Persentase PKP terhadap penghasilan bruto kondisi 1 sebesar 4,8\% (Rp 11.470.147/Rp 240.173.836), sedangkan kondisi 2 sebesar -23,8\% (Rp 63.009.776/Rp 265.284.916).

Dari kedua variabel tersebut dapat ditentukan titik impas antara tarif Pasal 17 Ayat (1) UU PPh dan PP 46 sebagai berikut:

PPh Terutang Pasal 17 Ayat (1) UU PPh $=$ PPh PP 46

$$
\begin{gathered}
25 \% \text { PKP }=1 \% \text { Omzet } \\
\text { PKP }=1 \% / 25 \% \text { Omzet } \\
\text { PKP }=4 \% \text { Omzet }
\end{gathered}
$$

Persamaan di atas menggambarkan bahwa titik impas dari perhitungan Pajak Penghasilan terutang menurut ketentuan Pasal 17 Ayat (1) UU PPh dan PP 46 berada pada titik 4\%. Apabila dihubungkan dengan penghitungan pajak terutang PT Ghaffa Fishery yang telah dilakukan, kondisi 1 yang memiliki presentasi PKP 4,8\% terhadap omzetnya memiliki beban pajak yang lebih ringan apabila menggunakan perhitungan $\mathrm{PPh}$ terutang sesuai ketentuan PP 46. Sebaliknya, kondisi 2 yang memiliki persentase PKP terhadap omzetnya lebih kecil dari $4 \%$ akan memiliki beban pajak yang lebih ringan apabila menghitung pajak terutangnya berdasarkan ketentuan Pasal 17 Ayat (1) UU PPh.

PP 46 dapat disimpulkan akan lebih menguntungkan Wajib Pajak apabila diterapkan pada usaha yang tidak memiliki biaya yang relatif besar atau persentase Penghasilan Kena Pajaknya berada di atas 4\% dari omzetnya. Sedangkan bagi Wajib Pajak yang memiliki biaya usaha yang relatif besar akan lebih menguntungkan apabila menghitung pajak terutangnya berdasarkan Pasal 17 Ayat (1) UU PPh karena ketentuan ini mempertimbangkan biaya atau kerugian usaha yang dapat dikurangi dari beban pajak. 


\section{SIMPULAN}

1. Pemakaian omzet/peredaran bruto sebagai Dasar Pengenaan Pajak PP 46 sejalan dengan tujuan penerbitan peraturan ini, yaitu untuk kemudahan dan kesederhanaan bagi Wajib Pajak, karena apabila dasar yang digunakan adalah tambahan kemampuan ekonomis seperti yang disebut dalam Pasal 4 Ayat (1) UU PPh, maka Wajib Pajak harus menghitung berapa tambahan kemampuan ekonomisnya melalui pembukuan, di mana pengguna PP 46 yaitu pelaku UMKM tidak menggunakannya dan pastilah tujuan penerbitan peraturan ini tidak akan tercapai;

2. Walaupun Dasar Pengenaan Pajak yang diterapkan PP 46 yaitu peredaran bruto bertentangan dengan apa yang disebut penghasilan oleh UU PPh yaitu tambahan kemampuan ekonomis, akan tetapi hal tersebut tidak menyalahi aturan umum karena Pasal 17 Ayat (7) dan Pasal 4 Ayat (2) huruf e UU PPh dengan jelas memperbolehkan adanya jenis penghasilan yang dikenai tarif final tertentu;

3. Titik impas dari perhitungan Pajak Penghasilan terutang menurut ketentuan Pasal 17 Ayat (1) UU PPh dan PP 46 berada pada titik 4\%. Dengan demikian, dapat diketahui bahwa:

a. PP 46 akan lebih menguntungkan Wajib Pajak apabila diterapkan pada usaha yang tidak memiliki biaya yang relatif besar atau persentase Penghasilan Kena Pajaknya berada di atas 4\% dari omzetnya. Sedangkan bagi Direktorat Jenderal Pajak, potensi pajak akan lebih besar apabila PP 46 digunakan sebagai ketentuan dalam menghitung PPh terutang Wajib Pajak yang jumlah Penghasilan Kena Pajaknya kurang dari 4\% terhadap omzetnya.

b. Bagi Wajib Pajak yang memiliki biaya usaha yang relatif besar akan lebih menguntungkan apabila menghitung Pajak Penghasilan terutangnya berdasarkan Pasal 17 Ayat (1) UU PPh karena ketentuan ini mempertimbangkan biaya atau kerugian usaha yang dapat dikurangi dari beban pajak. Sebaliknya, apabila dilihat dari sisi Direktorat Jenderal Pajak, 
penghitungan PPh terutang menggunakan Pasal 17 Ayat (1) UU PPh bagi Wajb Pajak yang jumlah Penghasilan Kena Pajaknya di atas 4\% dari omzetnya menghasilkan potensi pajak yang lebih besar.

\section{DAFTAR PUSTAKA}

Anjarwati, Ratna. 2013. PPh Final 1\% untuk UMKM. Yogyakarta: Pustaka Baru Press. Budi, Chandra. 2013. Urus Pajak Itu Sangat Mudah. Jakarta: PT Elex Media.NJ Feldmann. 1949. De overheidsmiddelen van Indonesië in verband met de dualistische economie. California: Stenfert Kroese.

Ibrahim, Syarif. 2013. Pengenaan PPh Final Untuk Wajib Pajak Dengan Peredaran Bruto Tertentu, Sebuah Konsep Kesederhanaan Pengenaan PPh Untuk Meningkatkan Voluntary Tax Compliance. Jakarta: Pusat Kebijakan Pendapatan Negara-Badan Kebijakan Fiskal.

Judisseno, Rimsky K. 2004. Perpajakan. Jakarta: Gramedia Pustaka Utama.

Seligman, Edwin Robert Anderson. 1905. Essays in Taxation. United States: Obscure Press.

Smeets, Mathieu Jacob Hubert. 1951. De economische betekenis van de belastingen. Amsterdam: Veen.

Smith, Adam. 1776. An Inquiry into the Nature and Causes of the Wealth of Nations. Edinburgh: Thomas Nelson.

Soemahamidjaja, Soeparman. 1964. "Pajak Berdasarkan Asas Gotong Royong”. Disertasi. Bandung: Universitas Padjajaran.

Soemitro, Rochmat. 1977. Dasar-Dasar Hukum Pajak dan Pajak Pendapatan. Bandung: Eresco.

Supramono dan Theresia Woro Damayanti. 2010. Perpajakan IndonesiaMekanisme dan Perhitungan. Yogyakarta: ANDI.

Anonim. 2008. Klasifikasi UMKM.

https://www.infoukm.wordpress.com/2008/08/29/klasifikasi-ukm.html (diakses 10 Mei 2017) 


\section{Dokumen dari internet}

Agusta, Rizki. 2015. Pengertian Pajak Menurut Para Ahli. http://semuapengertian.blogspot.co.id/2015/02/pengertian-pajakmenurut-para-ahli.html (diakses 11 April 2017)

Badan Pusat Statistik. 2015. Profil Industri Mikro dan Kecil Tahun 2015. https://www.bps.go.id/website/pdf_publikasi/Profil-Industri-Mikro-danKecil-2015-.pdf (diakses 27 April 2017) . 2016. Perkembangan Indeks Produksi Triwulanan Industri Mikro dan Kecil 2014-2016. https://www.bps.go.id/website/pdf_publikasi/Perkembangan-Indeks-ProduksiTriwulanan-Industri-Mikro-dan-Kecil-2014-2016--.pdf (diakses 27 April 2017)

2017. Laporan Bulanan Data Sosial Ekonomi-Maret 2017. https://www.bps.go.id/website/pdf_publikasi/Laporan-BulananData-Sosial-Ekonomi-Maret-2017.pdf (diakses 27 April 2017)

Direktorat Jenderal Pajak. 2015. Laporan Tahunan DJP 2014. http://www.pajak.go.id/content/laporan-tahunan-djp-2014 (diakses 24 Mei 2017)

2016. Laporan Tahunan DJP 2015. http://www.pajak.go.id/content/laporan-tahunan-djp-2015 (diakses 24 Mei 2017)

\section{Dokumen Publik dan Peraturan Perundang-Undangan}

Republik Indonesia. 2008. Undang-undang Republik Indonesia Nomor 16 Tahun 2009 tentang Perubahan Keempat Atas Undang-Undang Nomor 6 Tahun 1983 tentang Ketentuan Umum dan Tata Cara Perpajakan. Republik Indonesia. 2008. Undang-undang Republik Indonesia Nomor 36 Tahun 2008 tentang Perubahan Keempat Atas Undang-Undang Nomor 7 Tahun 1983 tentang Pajak Penghasilan. 
Republik Indonesia. 2008. Undang-undang Republik Indonesia Nomor 20 Tahun 2008 tentang Usaha Mikro, Kecil, dan Menengah.

Presiden Republik Indonesia. 2013. Peraturan Pemerintah Republik Indonesia Nomor 17 Tahun 2013 tentang Pelaksanaan Undang-Undang Nomor 20 Tahun 2008 Tentang Usaha Mikro, Kecil, dan Menengah.

Presiden Republik Indonesia. 2013. Peraturan Pemerintah Republik Indonesia Nomor 46 Tahun 2013 tentang Pajak Penghasilan atas Penghasilan dari Usaha yang Diterima atau Diperoleh Wajib Pajak yang Memiliki Peredaran Bruto Tertentu. 